\title{
How COVID-19 pandemic affect nutritional status
}

\author{
Pittara Pansawira ${ }^{1}$ \\ 1. Indonesian Nutrition Association, Jakarta, Indonesia
}

Received 26 August 2021

Accepted 26 August 2021

Link to DOI:

10.25520/WNJ.V04.i2.0002

Journal Website:

www.worldnutrijournal.org

The outbreak of COVID-19, a disease caused by SARS-CoV-2, has subsequently forced partial lockdowns in many countries. In the past two years, most preschool, school-aged, and young adults have to do online classes, courses, colleges, jobs and meetings, which may alter their daily life. This include changes in nutritional intakes and physical activities. These changes may result in either increased of obesity or malnutrition. It is well known that obesity and malnutrition may worsen the outcomes of COVID-19 infection. If not infected, they may also worsen quality of life.

Many studies have been done in the past year regarding nutritional behaviors during the COVID19 lockdowns. A study in Germany to 1964 young adults reported $31.2 \%$ of participants had increased the amount of food intakes. ${ }^{1}$ In Spain, a study resulted that people consumed $539 \mathrm{kcal}$ more than the recommendation during lockdown. ${ }^{2}$ Similar to these studies, a study in Poland showed that $43 \%$ and $52 \%$ of the participants reported eating and snacking more, respectively. ${ }^{3}$

In Indonesia, COVID-19 has primarily affected food access and causes drop of income. The poor and vulnerable groups have difficulties in affording high nutritional value food thus resulting in, not only decline of food intake, but also lower dietary quality. ${ }^{4}$

Regarding physical activity, a survey study showed $45.6 \%$ of 90 participants had low physical activity during the quarantine. ${ }^{5}$ On the contrary, a comparative study to 147 Malaysian and 107 Indonesian students showed increased of physical activities in $79.6 \%$ Malaysian and $77.6 \%$ Indonesian. ${ }^{6}$

In relation to Indonesian children's nutritional status, COVID-19 pandemic disturbs Posyandu (small integrated healthcare center for mother and children) activities. This results in delay in detection of malnutrition in children. ${ }^{7-9}$ There is also concern regarding the increased of micronutrient deficiencies among children, mainly iron.

Currently, it is still a long journey until the end of COVID-19 pandemic. Global strategy of intervention may be required to combat detrimental nutritional status due to the quarantine.

\section{Conflict of Interest}

Authors declared no conflict of interest regarding this article.

\footnotetext{
Corresponding author:

Pittara Pansawira, MD

Indonesian Nutrition Association,

Wisma Nugraha, $5^{\text {th }}$ Floor, Suite 501,

Jl. Raden Saleh Raya No.6, Jakarta, Indonesia

Email:worldnutritionjournal@gmail.com
} 


\section{Open Access}

This article is distributed under the terms of the Creative Commons Attribution 4.0 International Licence

(http://creativecommons.org/licenses/by/4.0/), which permits unrestricted use, distribution, and reproduction in any medium, provided you give appropriate credit to the original author(s) and the source, provide a link to the Creative Commons license, and indicate if changes were made.

\section{References}

1. Huber BC, Steffen J, Schlichtiger J, Brunner S. Altered nutrition behavior during COVID-19 pandemic lockdown in young adults. Eur J Nutr. 2021 Aug;60(5):2593-602.

2. Batlle-Bayer L, Aldaco R, Bala A, Puig R, Laso J, Margallo $\mathrm{M}$, et al. Environmental and nutritional impacts of dietary changes in Spain during the COVID19 lockdown. Sci Total Environ. 2020 Dec;748:141410.

3. Sidor A, Rzymski P. Dietary Choices and Habits during COVID-19 Lockdown: Experience from Poland. Nutrients. 2020 Jun 3;12(6):1657.

4. Sirojuddin A, Widjajanti I, Ramadhan Fatah A, Tamys AR. SMERU Research Report: Strategic review of food security and nutrition in Indonesia. World Food Programme; 2020.

5. Bachtiar F, Condrowati, Utari D, Maharani FT. Physical activity levels of adults during COVID-19 quarantine in Indonesia: A cross-sectional descriptive study. Advances in Health Sciences Research. 2020;30:267-73.

6. Tan S, Tan C, Tan S. Physical Activity, Sedentary Behavior, and Weight Status of University Students during the COVID-19 Lockdown: A Cross-National Comparative Study. Int J Environ Res Public Health. 2021 Jul 3;18(13):7125.
7. Paramashanti BA. Opinion: Challenges for Indonesia Zero Hunger Agenda in the Context of COVID-19 Pandemic. Kesmas Natl Public Health J [Internet]. 2020 Jul 27 [cited 2021 Aug 23];15(2). Available from: http://journal.fkm.ui.ac.id/kesmas/article/view/3934

8. Perwiraningrum DA, Elisanti AD, Amareta DI, Werdiharini AE. Need assessment of stunted children during pandemic Covid-19 to develop nutrition intervention program in Jember district, East Java, Indonesia. Advances in Social Science, Education and Humanities Research. 2021;514:160-4.

9. Efrizal W. Berdampakkah pandemi COVID-19 terhadap stunting di Bangka Belitung? JKKI. 2020;9(3):154-7. 